\title{
Cas Scaffolding Protein Family Member 4
}

National Cancer Institute

\section{Source}

National Cancer Institute. Cas Scaffolding Protein Family Member 4. NCI Thesaurus.

Code C162371.

Cas scaffolding protein family member 4 (786 aa, $\sim 87 \mathrm{kDa}$ ) is encoded by the human CASS4 gene. This protein is involved in the positive regulation of tyrosine kinasemediated signaling. 